\title{
RELATIONSHIP BETWEEN THE ANATOMY AND DRYING IN Eucalyptus grandis X Eucalyptus urophylla WOOD ${ }^{1}$
}

Antônio José Vinha Zanuncio ${ }^{2 *}$, Amélia Guimarães Carvalho ${ }^{2}$, Renato Augusto Pereira Damásio ${ }^{2}$, Bráulio da Silva de Oliveira ${ }^{3}$, Angélica de Cassia Oliveira Carneiro ${ }^{4}$ and Jorge Luiz Colodette ${ }^{4}$

\footnotetext{
${ }^{1}$ Recebido em 10.09.2014 aceito para publicação em 10.03.2016.

${ }^{2}$ Universidade Federal de Viçosa, Programa de Pós-Graduação em Ciência Florestal, Viçosa, MG - Brasil. E-mail: <ajvzanuncio@yahoo.com.br>, <ameliagcarvalho@gmail.com> and $<$ damasiorenato@gmail.com>

${ }^{3}$ Universidade Federal de Viçosa, UFV - Brasil. E-mail: <brawlyo_bso@hotmail.com>.

${ }^{4}$ Universidade Federal de Viçosa, Departamento de Engenharia Florestal, Viçosa, MG - Brasil. E-mail: <cassiacarneiro1@gmail.com> and $<$ colodett@ufv.br>.

*Corresponding author.
}

\begin{abstract}
Drying is an important step to using wood and anatomical characteristics influence this process. Thus, the objective of this work was to evaluate the relationship between anatomy and wood drying. Samples with $2 \times 2 \times 4 \mathrm{~cm}$ were obtained from eight Eucalyptus urophylla $\times$ Eucalyptus grandis clones at $1.3 \mathrm{~m}$ height to evaluate the anatomy and drying in climate chamber during 15 days. Cell wall fraction was established as the parameter that best correlated with drying, the Pearson correlation coefficient between this parameter and moisture was $-0.8986,-0.6580,0.9216,0.8743,0.7131$ and 0.8727 for saturated wood, and after $1,2.5$, 5,10 and 15 days of drying, respectively. The frequency and vessel size, as well as the height and width of the rays showed low relation with wood drying. Wood anatomy, mainly the cell wall fraction, influences moisture losses and should be considered in wood drying programs.
\end{abstract}

Keywords: Cell wall fraction; Eucalyptus; Moisture.

\section{RELAÇÃO ENTRE A ANATOMIA E A SECAGEM DA MADEIRA DE Eucalyptus grandis $X$ Eucalyptus urophylla}

\begin{abstract}
RESUMO - A secagem é uma importante etapa para utilização da madeira e as características anatômicas influenciam neste processo. Desse modo, o objetivo foi avaliar a relação entre a anatomia e a secagem da madeira. Amostras de $2 \times 2 \times 4 \mathrm{~cm}$ de madeira foram retiradas de oito materiais de Eucalyptus grandis $x$ Eucalyptus urophylla, a 1,3 metros acima do solo para avaliação da anatomia e secagem em câmara climática durante 15 dias. A perda de umidade foi maior nos primeiros dias de secagem e todos os materiais alcançaram a umidade de equilíbrio com 15 dias de secagem. A fração parede foi o parâmetro que melhor se relacionou com a secagem, sendo que o coeficiente de correlação de Pearson entre este parâmetro e a umidade foi de -0,8986; -0,6580;0,9216;0,8743;0,7131 e 0,8727 para a madeira saturada e após 1; 2,5; 5; 10 e 15 dias de secagem, respectivamente. O diâmetro e a frequência de vaso e a altura e a largura dos raios mostraram baixa relação com a secagem. A anatomia, principalmente a fração parede, influenciou a perda de umidade e por isto, deve ser considerada na elaboração de programas de secagem da madeira.
\end{abstract}

Palavras-chave: Eucalipto; Fração parede; Umidade. 


\section{INTRODUCTION}

The wood moisture content reduces the calorific value and carbonization yield (SWITHENBANK et al., 2011; ZANUNCIO et al., 2013a), worsens the mechanical properties (ENGELUND et al., 2013; BELTRAME et al., 2013), increases the transport costs (ZHU et al., 2011) and can cause defects such as cracks and warping (REBOLLEDO et al., 2013), making wood drying an essential process.

Drying is more intense in wood having high humidity, with free water loss, which is held by weak intermolecular bonds (SKAAR, 1972). The wood reaches the fiber saturation point (FSP) between 20 and $35 \%$ (KOLLMANN; CÔTÉ, 1968; BAL; BEKTAS, 2012; ZANUNCIO et al., 2014). This moisture range indicates that all free water has been removed, remaining the water of adsorption. This water is held in the wood by hydrogen bonds which require higher energy expenditure for its removal, reducing the drying process until the wood reaches the equilibrium moisture content (REZENDE et al., 2010; ENGELUND et al., 2013). The water of constitution, which is an essential part of the wood structure, can only be removed by wood degradation (SIAU, 1971).

Moisture in living trees varies with the annual seasons, genetic material, between parts of the same individual (BEDANE et al., 2011; BRAND et al., 2011; ANANIAS et al., 2013a) and factors inherent to the wood, including density, anatomical structure and piece size in concern (REZENDE et al., 2010; ZANUNCIO et al., 2013b).

The drying process depends upon the raw material and, therefore, further study is warranted. The aim of this study was to evaluate the relationship between anatomy and wood drying in Eucalyptus grandis $\mathrm{x}$ Eucalyptus urophylla wood.

\section{MATERIALAND METHODS}

Six materials with two-year-old (clones A, B, C, D, E and F) and two materials with seven-year-old (clones $\mathrm{G}$ and $\mathrm{H}$ ) of Eucalyptus grandis $\mathrm{x}$ Eucalyptus urophylla clones were studied, utilizing three trees per sample material. These trees were harvested and a 0.5 meters $\log$ was removed from 1.3 meters above ground level. Then, The logs were cut to get samples with $2 \times 2 \times 4 \mathrm{~cm}$. In each tree, was removed 10 samples

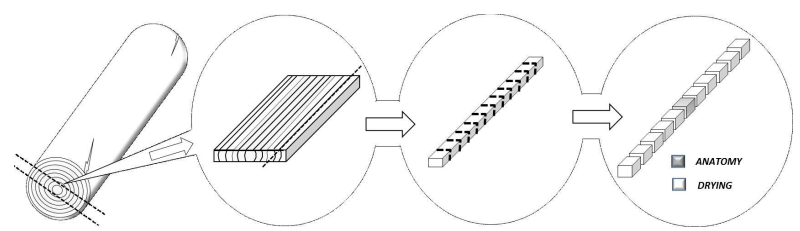

Figure 1-Removal of the specimens of each of the eight Eucalyptus grandis $\mathrm{x}$ Eucalyptus urophylla clones for drying experiments.

Figura 1-Remoção das amostras de cada um dos oito clones de Eucalyptus grandis $x$ Eucalyptus urophylla para experimentos de secagem.

for evaluation of drying and one for anatomical evaluation (Figure 1).

The microscopic description of the wood was done according to the International Association of Wood Anatomists - IAWA (1989), microscopic slides were prepared according to Johansen (1940) and macerated according to the recommendations of Franklin (1945).

A total of 75 measurements were recorded for anatomical parameter. In the histological sections, the diameter of the vessels and their frequency, as well as height and width of the rays were evaluated. In the macerated material, the length, width and lumen diameter of the fibers were measured. The cell wall thickness of the fibers was calculated employing the equation: $\mathrm{Cwt}=(\mathrm{Fw} \times \mathrm{Lw}) / 2$, and the cell wall fraction according to the equation: $\mathrm{Cwf}=(2 \times \mathrm{Cwt}) / \mathrm{Fw}) \times 100$, where, $\mathrm{Wt}=$ wall thickness $(\mu \mathrm{m}) ; \mathrm{Fw}=$ fiber width $(\mu \mathrm{m})$; $\mathrm{Lw}=$ lumen width; $\mathrm{Cwf}=\mathrm{Cell}$ wall fraction $(\%)$.

The averages of the anatomical parameters were subjected to the Scott-Knott test at 5\% probability.

The wood samples were saturated to constant weight and exposed to the drying process in a climatic chamber at $23^{\circ} \mathrm{C}$ with $50 \%$ relative humidity. The specimens were weighed twice a day in the first week and once a day over the following eight days. The moisture on a dry basis was determined according to NBR 1 1941: 2003.

The relationship between the anatomy and wood drying was analyzed by the Pearson correlation coefficient.

\section{RESULTS}

\subsection{Anatomical analysis}

The anatomical parameters evaluated differed between the genetic materials analyzed (Table 1). This 
Table 1 - Anatomical analysis of eight Eucalyptus grandis x Eucalyptus urophylla clones.

Tabela 1 - Análise anatomica das amostras dos oito clones de Eucalyptus grandis $x$ Eucalyptus urophylla.

\begin{tabular}{|c|c|c|c|c|c|}
\hline Cl. & F.L. $(\mathrm{mm})$ & F.D. $(\mu \mathrm{m})$ & L.D. $(\mu \mathrm{m})$ & C.W.T. $(\mu \mathrm{m})$ & C.W.F. (\%) \\
\hline $\mathrm{A}$ & $0.93^{12.5} \mathrm{c}$ & $20.1^{13.6} \mathrm{~d}$ & $12.1^{14.2} \mathrm{c}$ & $4.0^{15.2} \mathrm{c}$ & $39.7^{13.4} \mathrm{a}$ \\
\hline $\mathrm{B}$ & $0.89^{12.2} \mathrm{~b}$ & $20.1^{15.1} \mathrm{~d}$ & $12.3^{16.4} \mathrm{c}$ & $3.9^{16.0} \mathrm{c}$ & $39.2^{13.8} \mathrm{a}$ \\
\hline $\mathrm{C}$ & $0.87^{14.5} \mathrm{~b}$ & $18.1^{14.3} \mathrm{c}$ & $10.2^{17.2} \mathrm{~b}$ & $3.9^{17.4} \mathrm{c}$ & $43.6^{13.7} \mathrm{~b}$ \\
\hline $\mathrm{D}$ & $0.79^{11.2} \mathrm{a}$ & $15.7^{12.4} \mathrm{a}$ & $8.9^{17.4} \mathrm{a}$ & $3.4^{16.8} \mathrm{a}$ & $43.3^{12.6} \mathrm{~b}$ \\
\hline $\mathrm{E}$ & $0.90^{10.3} \mathrm{~b}$ & $16.6^{11.2} \mathrm{~b}$ & $9.2^{15.6} \mathrm{a}$ & $3.7^{15.2} \mathrm{~b}$ & $45.1^{13.2} \mathrm{c}$ \\
\hline $\mathrm{F}$ & $0.82^{14.5} \mathrm{a}$ & $17.6^{15,2} \mathrm{c}$ & $10.5^{16.8} \mathrm{~b}$ & $3.6^{16.6} \mathrm{~b}$ & $41,0^{14.5} \mathrm{a}$ \\
\hline G & $1.00^{10.2} \mathrm{~d}$ & $18.1^{11.4} \mathrm{c}$ & $9.8^{14.3} \mathrm{~b}$ & $4.2^{13.6} \mathrm{~d}$ & $46.2^{11.3} \mathrm{~d}$ \\
\hline $\mathrm{H}$ & $1.00^{12.1} \mathrm{~d}$ & $17.5^{16.3} \mathrm{c}$ & $9.1^{15.4} \mathrm{a}$ & $4.2^{12.7} \mathrm{~d}$ & $48.1^{12.4} \mathrm{e}$ \\
\hline & \multicolumn{2}{|c|}{ Vessel diameter $(\mu \mathrm{m})$} & $\left.\mathrm{m}^{2}\right)$ & \multicolumn{2}{|c|}{ Ray width $(\mu \mathrm{m})$} \\
\hline $\mathrm{A}$ & \multicolumn{2}{|c|}{$100.1^{10.2} \mathrm{c}$} & & \multicolumn{2}{|c|}{$8.5^{18.3} \mathrm{~d}$} \\
\hline $\mathrm{B}$ & \multicolumn{2}{|c|}{$119.2^{12.3} \mathrm{e}$} & & \multicolumn{2}{|c|}{$6.9^{19.2} \mathrm{~b}$} \\
\hline $\mathrm{C}$ & \multicolumn{2}{|c|}{$113.2^{11.6} \mathrm{~d}$} & & \multicolumn{2}{|c|}{$6.3^{16.5} \mathrm{~b}$} \\
\hline $\mathrm{D}$ & \multicolumn{2}{|c|}{$82.1^{10.5} \mathrm{~b}$} & & \multicolumn{2}{|c|}{$5.8^{15.3} \mathrm{a}$} \\
\hline $\mathrm{E}$ & \multicolumn{2}{|c|}{$77.5^{11.9} \mathrm{a}$} & & \multicolumn{2}{|c|}{$7.4^{15.8} \mathrm{c}$} \\
\hline $\mathrm{F}$ & \multicolumn{2}{|c|}{$109.6^{11.5} \mathrm{~d}$} & & \multicolumn{2}{|c|}{$7.6^{16.4} \mathrm{c}$} \\
\hline G & \multicolumn{2}{|c|}{$113.2^{12.5} \mathrm{~d}$} & & \multicolumn{2}{|c|}{$6.5^{17.2} \mathrm{~b}$} \\
\hline $\mathrm{H}$ & \multicolumn{2}{|c|}{$129.4^{10.6} \mathrm{f}$} & & \multicolumn{2}{|c|}{$6.5^{15.6} \mathrm{~b}$} \\
\hline
\end{tabular}

CL.=Eucalyptus grandis $x$ Eucalyptus urophylla clone; F.L. = Fiber length; F.D.= Fiber diameter; L.D.= Lumen diameter; C.W.T. $=$ Cell wall thickness; C.W.F.= Cell Wall Fraction; Freq.=Vessel Frequency. Means followed by the same letter vertically by parameter does not differ by the Scott-Knott test at $5 \%$. Values in superscript represent the coefficient of variation.

$C L .=$ clone de Eucalyptus grandis $\boldsymbol{x}$ Eucalyptus urophylla; F.L. = Comprimento da fibra; F.D = Diâmetro da fibra; L.D. = Diâmetro do lume; C.W.T. = Espessura da parede celular; C.W.F.= Fração de parede celular; Freq. = Freqüência de vasos. Médias seguidas pela mesma letra na vertical por parâmetro não diferem pelo teste de Scott-Knott, a $5 \%$. Valores em sobrescrito representam o coeficiente de variação.

is important, because heterogeneous materials are mandatory to more accurately assess the impact of the anatomical parameters on the drying process.

\subsection{Wood Drying}

The initial moisture content of the clones ranged from 138.5 to $195.2 \%$, with different drying rates during the period evaluated; however, all of them achieved the equilibrium moisture content between 10.68 and $11.27 \%$ after this period (Table 2 ).

\subsection{Relationship between anatomy and drying}

The relationship between wood anatomy and drying showed the highest Pearson correlation coefficients for lumen diameter, cell wall width and cell wall fraction (Table 3).

Table 2 - Moisture in eight Eucalyptus grandis $\mathrm{x}$ Eucalyptus urophylla clones in the most representative periods for 15 days of drying.

Tabela 2 - Umidade em oito clones de Eucalyptus grandis $x$ Eucalyptus urophylla, nos periodos mais representativos dos 15 dias de secagem.

\begin{tabular}{|c|c|c|c|c|c|c|c|c|}
\hline \multirow[t]{2}{*}{ CL. } & \multicolumn{8}{|c|}{ Wood moisture content during drying (\%) } \\
\hline & Saturated wood & 0.5 days & 1 day & 1.5 days & 2.5 days & 5 days & 10 days & 15 days \\
\hline A & 189.0 & 145.8 & 102.9 & 67.6 & 30.2 & 12.8 & 11.4 & 10.8 \\
\hline $\mathrm{B}$ & 195.2 & 148.1 & 102.7 & 66.6 & 28.2 & 12.5 & 11.5 & 10.6 \\
\hline $\mathrm{C}$ & 180.0 & 139.9 & 107.4 & 70.1 & 39.7 & 13.7 & 11.5 & 10.9 \\
\hline $\mathrm{D}$ & 179.1 & 132.3 & 96.0 & 62.3 & 34.3 & 13.4 & 11.4 & 11.2 \\
\hline $\mathrm{E}$ & 159.2 & 127.6 & 98.5 & 76.3 & 48.9 & 15.8 & 11.6 & 11.2 \\
\hline $\mathrm{F}$ & 191.8 & 147.4 & 105.1 & 64.5 & 28.4 & 12.8 & 11.6 & 10.8 \\
\hline G & 138.4 & 108.9 & 87.1 & 71.0 & 46.2 & 15.8 & 11.9 & 11.1 \\
\hline $\mathrm{H}$ & 153.6 & 120.5 & 94.9 & 78.8 & 47.2 & 15.0 & 11.7 & 11.2 \\
\hline
\end{tabular}

$\mathrm{CL} .=$ Eucalyptus grandis $x$ Eucalyptus urophylla clone.

$C L .=$ clone de Eucalyptus grandis $x$ Eucalyptus urophylla. 
Table 3 - Pearson correlation coefficient between the anatomy and moisture in saturated wood and after 1, 2.5, 5, 10 and 15 days drying in eight Eucalyptus grandis $\mathrm{x}$ Eucalyptus urophylla clones.

Tabela 3 - Coeficiente de correlação de Pearson entre a anatomia e umidade na madeira saturada e depois de 1; 2,5; 5; 10 e 15 dias de secagem em oito clones de Eucalyptus grandis $x$ Eucalyptus urophylla.

\begin{tabular}{|c|c|c|c|c|c|c|}
\hline Anatomical parameter & Saturated wood & 1 day & 2.5 days & 5 days & 10 days & 15 days \\
\hline F.L. $(\mathrm{mm})$ & -0.6882 & -0.5475 & 0.5852 & 0.5932 & 0.7218 & 0.1900 \\
\hline F.D. $(\mu \mathrm{m})$ & 0.3843 & 0.3180 & -0.4648 & -0.4499 & -0.1149 & -0.8294 \\
\hline L.D. $(\mu \mathrm{m})$ & 0.6537 & 0.5053 & -0.7156 & -0.6814 & -0.3803 & -0.9459 \\
\hline C.W.T. $(\mu \mathrm{m})$ & -0.5018 & -0.3212 & 0.4265 & 0.3983 & 0.6149 & -0.0552 \\
\hline C.W.F. $(\%)$ & -0.8986 & -0.6580 & 0.9216 & 0.8743 & 0.7131 & 0.8727 \\
\hline Vessel diameter $(\mu \mathrm{m})$ & -0.3044 & -0.0183 & 0.4063 & 0.3596 & 0.6398 & -0.0752 \\
\hline Freq. (poros $/ \mathrm{mm}^{2}$ ) & -0.1032 & -0.148 & 0.1884 & 0.2226 & -0.2525 & 0.5635 \\
\hline Ray height $(\mu \mathrm{m})$ & 0.1108 & 0.1078 & -0.2821 & -0.2059 & 0.3768 & -0.2463 \\
\hline Ray width $(\mu \mathrm{m})$ & 0.3403 & 0.3749 & -0.3316 & -0.2617 & -0.1496 & -0.4834 \\
\hline
\end{tabular}

F.L. = Fiber length; F.D. = Fiber diameter; L.D.= Lumen diameter; C.W.T. = Cell wall thickness; C.W.F.= Cell Wall Fraction; Freq.= Vessel Frequency.

F.L. = Comprimento da fibra; F.D= Diâmetro da fibra; L.D. = Diâmetro do lume; C.W.T. = Espessura da parede celular; C.W.F.= Fração de parede celular; Freq. = Freqüência de vasos.

\section{DISCUSSION}

\subsection{Anatomical analysis}

Seven-year-old clones, $\mathrm{G}$ and $\mathrm{H}$, revealed longer fibers with thicker walls and higher cell wall fractions. This difference could be due to the genetic material and environmental conditions (PILLAI et al., 2013) or plant age (SILVA et al., 2007). The growing size of the fiber with advancing age concurs with that reported for Eucalyptus grandis and Eucalyptus globulus (RAMÍREZ et al., 2009; RAMOS et al., 2011). A greater cell wall fraction increases the basic density (SETTE JR et al., 2012), which in turn improves the mechanical properties rendering the wood more resistant (ABRUZZI et al., 2012).

In fiber classification, the lumen diameter and cell wall thickness showed higher coefficients of variation. In the evaluation of the histological sections, the highest values for the coefficient of variation were found for the height and width of the rays, showing the wood anatomical constituents with higher variation.

\subsection{Wood Drying}

The water losses in the eucalyptus clones were higher during the first days of drying, similar to that reported for Eucalyptus urophylla logs (REZENDE et al., 2010; ZANUNCIO et al., 2013b) and Pinus radiata and Eucalyptus dunnii lumber (ANANIAS et al., 2013b; SEVERO et al., 2013). During this period, the loss of free water occurs because the weak capillary bonding between the wood and the water molecules gets easily broken, favoring water loss from the wood (KOLLMANN; CÔTÉ, 1968).
The clones B and G showed the highest and lowest moisture content after saturation, respectively. However, the first material lost $47.1,45.3$ and $36.1 \%$ of its moisture after $0.5,1.0$ and 1.5 days drying, respectively, while the second lost 29.6. 21.8 and 16.1\% over the same time period. Thus, after 1.5 days drying, clone $\mathrm{B}$ showed lower moisture content than clone $\mathrm{G}$ and this trend was repeated until the culmination of the drying process (Table 2). Maximum moisture content is associated with the empty spaces within the timber, including the vessels and cell lumens (SKAAR, 1972). These spaces facilitate water flow and promote drying (ZANUNCIO et al., 2015). The fact that materials with higher initial moisture show a higher drying rate was also reported for the Eucalyptus urophylla and Corymbia citriodora logs (REZENDE et al., 2010; ZANUNCIO et al, 2013b).

The highest drying rate of the materials $\mathrm{A}, \mathrm{B}, \mathrm{C}$, $\mathrm{D}$ and $\mathrm{F}$ enabled them to achieve moisture equilibrium within approximately six days, while the others reached this plateau at around eight days.

\subsection{Relationship between anatomy and drying}

The relationship between lumen diameter and cell wall thickness with drying was higher than that of fiber length and drying, because the water passed through the fibers in the cross direction during the drying process (SKAAR, 1972; ENGELUND etal., 2013). Lumen diameter and cell wall thickness influenced the wood drying in different way (KOLLMANN; CÔTÉ, 1968; TARMIAN; PERRÉ, 2009). These parameters can be related to only one variable, the cell wall fraction, which showed a greater relationship with drying. 
The Pearson correlation coefficient between cell wall fraction and moisture was positive from 2.5 days of drying, in which materials with lower cell wall fraction values began to experience lesser moisture due to their higher drying rate. Therefore, materials with higher cell wall fraction values have a lower void volume, resulting in lower moisture when saturated. A greater volume of fibers evades the passage of water and reduces the drying speed (KOLLMANN; CÔTÉ, 1968; DEROME et al., 2012).

The diameter and frequency of the vessels had a Pearson correlation coefficient value with drying always less than 0.65 , indicating that it does not influence wood drying. The vessel elements could have a greater influence on drying, because it facilitates the water transport within the wood (SIAU, 1971; AHMED, A.S.; CHUN, 2009). However, the water output during wood moisture losses occurs mostly by fiber diffusion (SKAAR, 1972), which explains the low ratio between the diameter and vessel frequency with drying.

\section{CONCLUSION}

Older materials (clones $\mathrm{G}$ and $\mathrm{H}$ ) showed fibers of greater length and cell wall fraction than younger materials. Moisture losses were higher during the initial drying stages and all the materials achieved equilibrium moisture content after 15 days of drying. The wood anatomy was related to moisture during all the periods. The cell wall fraction was the anatomical parameter that related the best, while diameter and vessel frequency and the height and width of the rays showed a low relationship with drying. Thus, wood anatomy should definitely be considered in the development of wood drying programs.

\section{ACKNOWLEDGEMENTS}

To "Conselho Nacional de Desenvolvimento Científico e Tecnológico (CNPq)", "Coordenação de Aperfeiçoamento de Pessoal de Nível Superior (CAPES)" and "Fundação de Amparo à Pesquisa do Estado de Minas Gerais (FAPEMIG)" for financial support. Global Edico Services corrected and edited the English of this manuscript.

\section{REFERENCES}

ABRUZZI, R.C.; PIRES, M.R.; DEDAVID, B.A.; KALIL, S.B. Relação das propriedades mecânicas e densidade de postes de madeira de eucalipto com seu estado de deterioração. Revista Árvore, v.36, n.6, p.1173-1181, 2012.

AHMED, A.S.; CHUN, S.K. Observation of liquid permeability related to anatomical characteristics in Samanea saman. Turkish Journal of Agriculture and Forestry, v.32, n.2, p.155$163,2009$.

ANANIAS, R.A.; PEREZ, P.; SALINAS, C.; ELUSTONDO, D. Drying schedules for canelo wood. Drying Technology: An International Journal, v.31, n.3, p.282-285, 2013a.

ANANIAS, R.A.; MENA, M.; ELUSTONDO, D.M.; DIAZ-VAZ, J.E.; VALENZUELA, L.; SALINAS, C. Testing new in-kiln meter for monitoring lumber moisture content during drying. Drying Technology: An International Journal, v,31, n.3, p.277-281, 2013b.

\section{ASSOCIAÇÃO BRASILEIRA DE NORMAS} TÉCNICAS - ABNT. BR 11941: madeira, determinação da densidade básica. Rio de Janeiro: 2003.6p.

BAL, B.C.; BEKTAS, I. The effects of heat treatment on physical properties of juvenile wood and mature wood of Eucalyptus grandis.

BioResources, v.7, n.4, p.5117-5127, 2012.

BEDANE, A.H.; AFZAL, M.T.; SOKHANSANJ, S Simulation of temperature and moisture changes during storage of woody biomass owing to weather variability. Biomass and Bioenergy, v.35, n.2, p.3147-3151, 2011

BELTRAME, R.; MATTOS, B.D.; GATTO, D.A.; LAZAROTTO, M.; HASELEIN, C.R. Resistência ao choque da madeira de Platanus $\mathrm{x}$ acerifolia em diferentes condições de umidade. Revista Árvore, v.37, n.4, p.771-778, 2013.

BRAND, M.A.; De MUÑIZ, G.I.B.; QUIRINO, W.F.; BRITO, J.O. Storage as a tool to improve wood fuel quality. Biomass and Bioenergy, v.35, n.7, p.2581-2588, 2011.

DEROME, D.; ZILLIG, W.; CARMELIET, J.

Variation of measured cross-

sectional cell dimensions and calculated water vapor permeability across a single growth ring of

Revista Árvore, Viçosa-MG, v.40, n.4, p.723-729, 2016

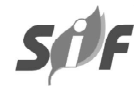


spruce wood. Wood Science and

Technology, v.46, n.5, p.827-840, 2012.

ENGELUND, E.T.; THYGESEN, L.G.; SVENSSON, S.; HILL, C.A.S. A critical discussion of the physics of wood-water interactions, Wood Science and Technology, v.47, n.1, p.141$161,2013$.

FRANKLIN, G.L. Preparation of thin sections of synthetic resins and wood: resin composites, and a new macerating method for wood.

Nature, v. 155, p. 51,1945

INTERNATIONAL ASSOCIATION OF WOOD ANATOMISTS -IAWA. List of microscope features for hardwood identification. IAWA Bulletin, v. 10, p.234-332, 1989.

JOHANSEN, D.A. Plant microtechnique. New York: McGraw-Hill, 1940. 523p.

KOllmann, F.F.P.; CÔTÉ, W.A. Principles of wood science and technology: solid wood. New York: Springer, 1968. v.1.592p.

PANSHIN, A.J.; DE ZEEUW, C. Textbook of wood technology. 4.ed. New York: McGrawHill Book, 1980. 722p.

PÉREZ-PEÑA, N. et al. Predicción del contenido de humedad de equilibrio de la madera en función del peso específico de la pared celular y variables ambientales. Maderas Ciencia y Tecnología, v.13, n.3, p.253-266, 2011.

PILLAI, P.H.C.; PANDALAI, R.C.; DHAMODARAN, T.K.; SANKARAN, K.V. Effect of silvicultural practices on fibre properties of Eucalyptus wood from short-rotation plantations. New Forests, v.44, n.4, p.521532,2013

RAMÍREZ, M.; RODRÍGUEZ, J.; PEREDO, M.; VALENZUELA, S.; MENDONÇA, R. Wood anatomy and biometric parameters variation of Eucalyptus globulus clones. Wood Science and Technology, v.43, n.2, p.131-141, 2009.

RAMOS, L.M.A.; LATORRACA, J.V.F.; PASTRO, M.S.; DE SOUZA, M.T.; GARCIA, R.A.; DE CARVALHO, A.M. Variação radial dos caracteres anatômicos da madeira de Eucalyptus grandis W. Hill Ex Maiden e idade de transição entre lenho juvenil e adulto. Scientia

Forestalis, v.39, n.92, p.411-418, 2011.

REBOLLEDO, P.; SALVO, L.; CONTRERAS, H.; CLOUTIER, A.; ANANIAS, R.A. Variation of internal checks related to anatomical structure and density in Eucalyptus nitens wood. Wood and Fiber Science, v.45, n.3, p.279-286, 2013.

REZENDE, R.N.; LIMA, J.T.; DA SILVA, J.R.M.; NAPOLI, A.; ANDRADE, H.B; FARIA, A.L.R. Air drying of logs from Eucalyptus urophylla clone for carbonization use. Cerne, v. 16, n.4, p.565-572, 2010.

SETTE JR, C.R.; DE OLIVEIRA, I.R.; TOMAZELLO FILHO, M.; YAMAJI, F.M.; LACLAU, J.P. Efeito da idade e posição de amostragem na densidade e características anatômicas da madeira de Eucalyptus grandis. Revista Árvore, v.36, n.6, p.1183-1190, 2012 .

SEVERO, E.T.D.; TOMASELLI, I.; CALONEGO, F.W.; FERREIRA, A.L.; MENDES, L.M. Effect of steam thermal treatment on the drying process of Eucalyptus dunnii variables. Cerne, v. 19, n.4, p.637-645, 2013.

SIAU, J.F. Flow in wood. Syracuse: Syracuse University, 1971. 245p.

SILVA, J.C.; TOMAZELLO FILHO, M.; OLIVEIRA, J.T.S.; DE CASTRO, V.R. Influência da idade e da posição radial nas dimensões das fibras e dos vasos da madeira de Eucalyptus grandis Hill ex. Maiden. Revista Árvore, v.31, n.6, p.1081-1090, 2007.

SKAAR, C.J. Water in wood. Syracuse: Syracuse University, 1972. 218p

SWITHENBANK, J.; CHEN, Q.; ZHANG, X.; SHARIFI, V.N.; POURKASHANIAN, M. Wood would burn. Biomass and Bioenergy, v.35, n.3, p.999-1007, 2011.

TARMIAN, A.; PERRÉ, P. Air permeability in longitudinal and radial directions of compression wood of Picea abies L. and tension wood of Fagus sylvatica L. Holzforschung, v.63, n.3, p.352-356, 2009. 
ZANUNCIO,A.J.V.; MONTEIRO T.C.; LIMA, J.T.; ANDRADE H.B.; CARVALHO, A.G. Biomass for energy use of Eucalyptus urophylla and Corymbia citriodora logs. BioResources, v.8, n.4, p.51595168, 2013a.

ZANUNCIO, A.J.V.; LIMA, J.T.; MONTEIRO, T.C.; CARVALHO, A.G.; TRUGILHO, P.F. Secagem de toras de Eucalyptus e Corymbia para uso energético. Scientia Forestalis, v.41, n.99, p.353-360, 2013b.

ZANUNCIO, A.J.V.; MOTTA, J.P.; DA SILVEIRA, T.A.; FARIAS, E.S.; TRUGILHO, P.F. Physical and colorimetric changes in Eucalyptus grandis wood after heat treatment. BioResources, v.9, n.1, p.293-302, 2014.

ZANUNCIO, A.J.V; CARVALHO, A.G.; DA SILVA, L.F.; LIMA, J.T.; TRUGILHO, P.F.; DA SILVA, J.R.M. Predicting moisture content from basic density and diameter during air drying of Eucalyptus and Corymbia logs. Maderas. Ciencia y tecnologia, v. 17, n.2, p.335-344, 2015.

ZHUA, X.; LIA, X.; YAO, Q.; CHEN, Y. Challenges and models in supporting logistics system design for dedicated-biomass-based bioenergy industry, Bioresource Technology, v.102, n.2, p.13441351, 2011. 